\title{
Economic Analysis of Community Forests in Terai Nepal
}

\author{
Ram Asheshwar Mandal*, Sampada Neupane \\ Kathmandu Forestry College And Environmental Science And Management, Kathmandu
}

\author{
*Corresponding Author: Ram Asheshwar Mandal, Ph D Kathmandu Forestry College and Environmental \\ Science and Management, Kathmandu.
}

\begin{abstract}
Community forest have great potential for contributing to the local economy to meet the subsistence needs and to improve natural resources management systems, leading to the conservation of a given ecosystem and its biodiversity. It is an autonomous institution so income, expenditure and administration management are mandatory. However, the economic analysis of community forests was rarely done. Therefore, this research was carried out to assess the trend of expenditure and the total annual expenses of the CF and to find the financial analysis of Community Forests. Three community forests namely Sansarkot Hariyali, Parijat community forest and Chisapani community forests were selected for the study. Total 30 key informant interview, three focus group discussion and observation was carried out. At the same time five years data of income and expenditure were collected from the record of community forest. The collected data were analyzed through economic analysis using $B / C$ ratio and NPV. The result showed that The total income was found to be highest in Chisapani CFUG (US\$177948.58) and the least in Parijat CFUG(US\$ 60136.82) in total during last five years. The highest amount of expenditure was found in Chisapani CFUG (US\$ 158082.01) and the least was in Parijat CFUG (US\$ 56381.49). The total profit is highest for the Chisapani CFUG (US\$19867.04) and least for the Parijat CFUG (US\$4210.51). The profit of Sansarkot Hariyali CFUG is US\$7820.75. The NPV and B/C is highest of the Chisapani CFUG i.e. US\$ 5322.69 and 1.11 and least of Parijat CFUG i.e. US\$3094.86 and 1.07. The NPV and B/C of Sansarkot Hariyali CFUG are US\$5322.69 and 1.11. The economic analysis can be supportive tool to show the performance of the community forests..
\end{abstract}

Keywords: $N P V, B / C$ ratio, Income, Expenditure.

\section{INTRODUCTION}

Nepal is the pioneer of community. To date, 19,361 community forestry user groups have been formed of which are composed of 1072 woman only committee members. A total of 18, 13,478 hectares of National forest have been handed over as community forests and 24, 61,549 households have benefited (DoF, 2016). Community forest have great potential for contributing to the local economy (Gilmour, and Fisher, 1991), to meet the subsistence needs and to improve natural resources management systems, leading to the conservation of a given ecosystem and its biodiversity (Acharya, 2001,). Most of the rural households depend upon the community forest resources for their daily living i.e. timber, fuel wood, fodder, forage etc. which also plays great role in their economy (G.C., 2016). There is very less economic mapping of these income sources of CFUGs and the expenses from these incomes gained.

Some studies in the cost-benefit of the community forests are reported, however there is still gap in knowledge for the status of the subject. The tenth five year plan of Nepal has also emphasized on poverty alleviation through community forestry by the management of forest product for income generation of rural user group. Initiation of the FUGs to generate income from proper management of the forest resources and the other sources i.e., organizational support, fine collection, etc. is one of the emerging issues in the community forests. Estimating the economic contribution of the community forest resources and the inequality of the derived income are the key steps towards understanding the role of community forestry in rural people day to day life (Chhetri 2006).

There are different sources of income in community forest. Indeed, the community forest users groups have been playing a significant role in forest management (Poudyal, Neil and Alesion, 2006). therefore; they were respected at local level and district level as well. They are appreciated when they transparently show their income and expenditure. It is worth full to list out and categorized the income 
sources annually as well as items and areas of expenditures are clearly maintained. However, these types of records are lacking in community forest users group which are helpful to add their value in federation of community forest Nepal at district level and district forest office. This research can moderate to listing and categorizing the income sources and items and areas of expenses.

The economic analysis of community is major part of transparency in any institution though the community forest users group is not profit oriented institution (Kanel and Kanel, 2004)n. The annual income and expenditure of community forest users group is used to carry out the economic analysis of their income and expenditure (Richards, Maharjan and Kanel, 2003). Such analysis has not been carried out by the community forest users group. Hence, this study was done to carry out the economic analysis of three community forests. The economic analysis includes the cost-benefit analysis $(\mathrm{B} / \mathrm{C})$ ratio and Net present value (NPV). It is very essential part of the community forest to show how the forest users have been benefited and how they have been managing the forest in the context of economic valuation. Therefore, this study was objectively carried out to to show the trend of expenditure and the total annual expenses of the community forest and to assess the financial analysis of community forests.

\section{Materials ANd Methodology}

Nawalparasi is a district made upof two areas namely Nawalpur area which is seated extending from North-west and Parasi area which is stretched from North West to Southwest.Nawalparasi is located in between the latitude of $2721^{\prime}$ to $2747^{\prime}$ North and longitude of 83 36' to $8435^{\prime}$ East where elevation ranges from $91 \mathrm{~m}$ to $1936 \mathrm{~m}$. The district is situated at Lumbini zone of western development region with Parasi as its district headquarters. Nawalparasi is extended in an area of 2162sq.km and lies $147 \mathrm{~km}$ west of Kathmandu.Three types of terrain are basically present in Nawalparasi namelyTerai (plain region) Pahaad (hilly region) and Bhitri Madesh region. The maximum temperature lies in between $20.5 \mathrm{C}$ to $36 \mathrm{C}$ with annual rainfall recorded to be $2145 \mathrm{~mm}$ in average. The total population of the district is $6,43,508$ which consists of 3, 39,833 females and 3,03,675 males with the total households of 1, 28,796 (DoF, 2015).

The study area is situated at the Bardaghat municipality of Nawalparasi district. Three community forests were selected for the study. The Shorea robust, Dalbergia sissoo, Terminalia tomentosa, Syzium cumuni etc are dominant vegetation.

i) Sansarkot Hariyali community forest: Sansarkot Hariyali CFUG is located at Bardaghat 10, Nawalparasi having total area of 475.63 ha. This CF was handed over to Sansarkot Hariyali community forest user group in BS 2057. The CF is boardered by Bhutaha settlement and Chapi Banshakti CF in the east, Tilakpur ward no.2 settlement and Pathaiya River in the west, Dhurkut 7 settlement and Mauladevi, Rittubarna CF in the north and Mahendra highway in the south. The CF is divided into 4 different blocks. The total number of household in the CF is 2,323 including 1252 males and 1071 females. Mainly teraibasi, Adibasi Janajati, Bhramin Chhetri are residing in the area. The user group committee consists of 19 members and 4 staff members.

ii) Parijat community forest: Parijat CFUG is located at Bardaghat 4, Nawalparasi having the total area of 199.28 ha. This CF was handed over to Parijat community forest user group in BS 2060. The CF is bordered by Sayapatri CF in the east, Chisapani CF in the west, Mahendra highway in the north and Awadhi and Badipidit road in the south. The CF is divided into 4 different blocks. The total number of household in the CF is 2,299 with the total population of 13,831 including 7,079 males and 6,752 females. Mainly adibasi janajati and terai basi are residing in the area. The user group committee consists of 13 members and the 4 staff members.

iii) Chisapani community forest: Chisapani CFUG is located at Bardaghat 2, Nawalparasi having total area of 495.76 ha. This CF was handed over to chisapani community forest user group in BS 2065 . The CF is bordered by chisapaniand Mainachaur River in the east, London Bridge and alawal, kamero and Birta River in the west, Jalkumbhi River in the north and mahendra highway in the west. The CF is divided into 5 different blocks. The total number of household in the CF is 3,350 with the total population of 18,550 including 9,421 males and 9,129 females. Mainly adibasi janajati and terai basi are residing in the area. The user group committee consists of 29 members and the 7 staff members.

Data collection: Both primary and secondary data were collected by using participatory Rural Appraisal tools and techniques (PRA). Primary data were collected from the study area using tools 
namely Reconnaissance survey, semi structured interview with key informants, focus group discussion, and direct observation of the was done while secondary data were collected from CFUGs report, operational plans and constitutions, DFO reports and other published and unpublished documents regarding the economic analysis of community forests.

Three focus group discussions were conducted to obtain qualitative information. In order to collect a variety of information and ideas regarding the economic condition their income and expenditure trend of CF. FGD was organized with selected CFUG members, VDC members, social leader and school teachers. Discussion focused on the annual income sources of each CFUG with their amount and the annual expenses sources from those incomes obtained. Thirty key informant's survey, ten from each was carried with the chairperson and the other executive committee members of the CFUG, social workers, local leaders and DFO staff. Observation visit was also carried out. The information about the income, expenses, and the benefit of the CFUG were obtained from these key informants.

Secondary data was gathered with the help of the published and unpublished documents and relevant literature regarding CFUGs economic analysis and its prospects and promotion. Secondary data was collected mainly to supplement primary data and for some new information as well. These data were collected from DFO Nawalparasi, Basabashai range post, Department of forest, constitution, FECOFUN,ICIMOD, KAFCOL library and various related websites.

\subsection{Data Analysis}

The collected primary and secondary data were qualitatively and quantitatively analyzed. The qualitative data were analyzed and interpreted in the form of text and tabular presentation while quantitative data were analyzed.

\subsection{Economic analysis}

The economic analysis was done employing Net Present Value (NPV), Benefit Cost Ratio (BC Ratio). Net Present Value (NPV)

Net present value is computed by finding the difference between the present worth of benefit stream less the present worth of cost stream. Or it is simply the present worth of the cash flow stream since it is a discounted cash flow measure of project worth along with internal rate of return.

NPV $=$ Present worth of Benefit Stream - Present Worth of Cost Stream.

Mathematically, it can be shown as, where,

$\mathrm{Bn}=$ benefits in each year of the project.

$\mathrm{Cn}=$ Costs in each year of the project.

$\mathrm{n}=$ number of years in a project

$\mathrm{i}=$ interest (discount) rate

$\mathrm{Bn}-\mathrm{Cn}=$ Cash flow in $\mathrm{n}_{\mathrm{th}}$ year of the project

The project is profitable or feasible if the calculated NVP is positive when discounted at the opportunity cost of capital.

Benefit Cost Ratio(BC Ratio): It is the ratio of present worth of benefit stream to present worth of cost stream i.e. Sum of the present worth of benefit

$\mathrm{B} / \mathrm{C}=$ Sum of the present worth of cost

Mathematically, it can be shown as, where,

$\mathrm{Bn}=$ Benefit in each year

$\mathrm{Cn}=$ Cost in each year

$\mathrm{n}=$ number of year

$\mathrm{i}=$ interest (discount) rates.

The investment is said to be profitable when the BCR is one or greater than 1 . This method is widely used in economic analysis and not in private investment analysis.

These values were calculated in US dollars, 1 USD =NRS 107.22 


\section{RESULTS AND DISCUSSIONS}

\subsection{Income of Cfugs from Various Sources}

\subsubsection{Income of Sansarkot Hariyali CFUG}

The total income of Sansarkot Hariyali CFUG in between 2012-2016 was US\$ 78818 out of that the contribution of Forest products is found to be highest i.e. 69.18\% (US\$ 54523.85). The income from forest products was highest in year 2016 i.e. US\$ 21640 and least in the year 2012 i.e. US\$3607.08. The contribution of household collection is least in total income of CF which is $4.86 \%$ (US\$3833.67), it was highest in the year 2014 (1319.20) and least in the year 2012 (546.07). The contribution of funds from DFO/Organizations was US\$8363.87 in total as the funds were only provided in year 2015(US\$2797.98) and year 2016 (US\$5565.89). Along with these sources other sources contributed US\$12097.53 in the total income of CF for the past five years (Figure 1).

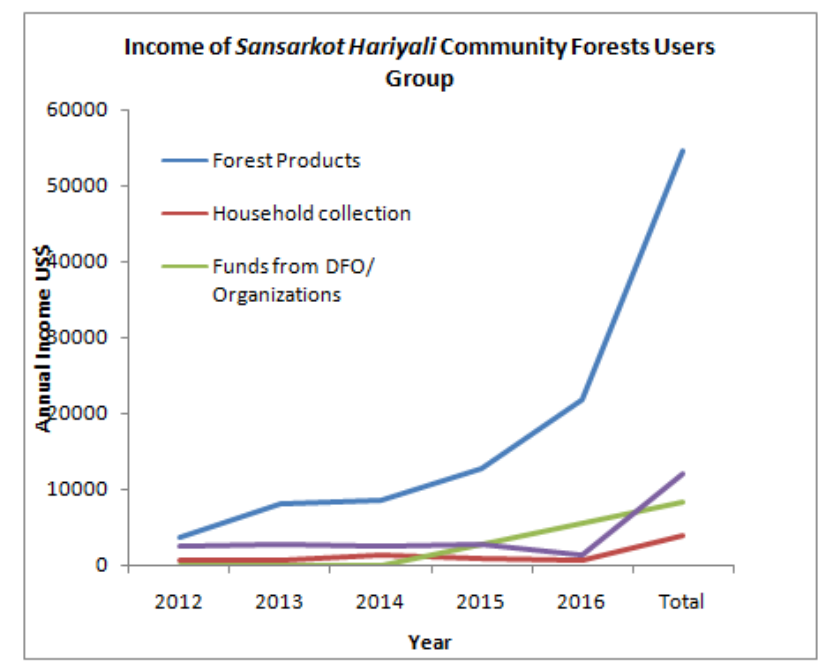

Figure1: Annual income of Sansarkot Hariyali CFUG from various sources in US

The total annual income was highest in the year 2016 i.e. US\$29178.90 and least in the year 2016 i.e. US\$29178.90. The total income has been constantly in the increasing order from year 2012 to the year 2016.

\subsubsection{Annual Income of Parijat CFUG}

The total income of Parijat CFUG in between 2012-2016 was US\$ 60136.82 out of that the contribution of Forest products is found to be highest i.e. $60.55 \%$ (US\$ 36414.97). The income from forest products was highest in year 2012 i.e. US\$ 10293.93 and least in the year 2015 i.e. US\$361.40. The contribution of funds from DFO/Organizations is least in total income of CF which is 3.10\% (US\$1865.33), the funds were available only for two years 2012(US\$932.67) and 2013(US\$932.66). The total contribution of Household Collection was US\$5322.99 which was highest collection in the year 2016 (US\$2095.87) and least in the year 2012 (US\$919.58). The other sources contributed US\$16533.53 in total (Figure 2).

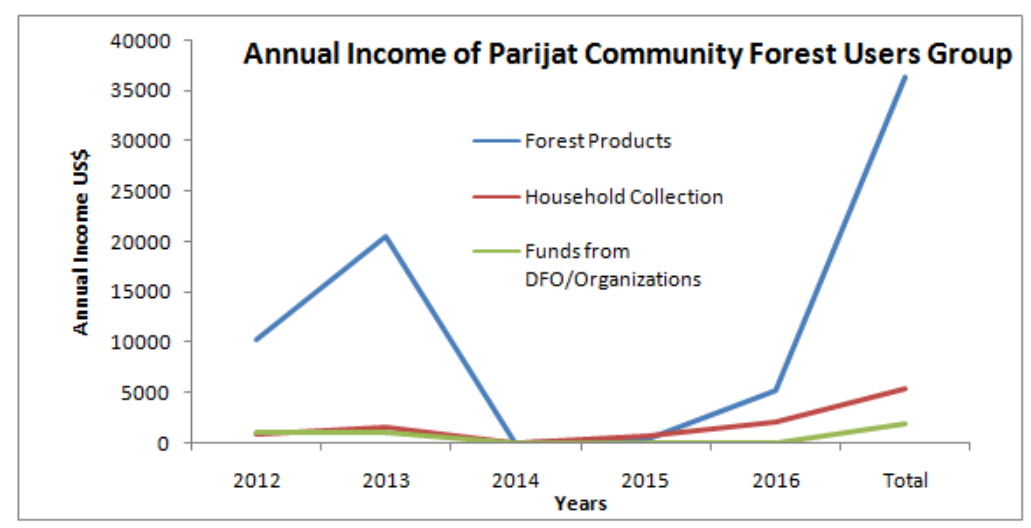

Figure2. Annual Income pf Paijat Community Forest 
The total annual income was highest in the year 2013 i.e. US\$27413.34 and least in the year 2015 i.e. US\$6658.51. The trend of total income is not constant, during second year the total income increased while in fourth year it decreased and again increased in last year.

\subsubsection{Income of Chisapani CFUG:}

The total income of Chisapani CFUG in between 2012-2016 was US\$177948.58 out of that the contribution of Forest products is found to be highest i.e. 57.56\% (US\$ 102400.79). The income from forest products was highest in year 2014 i.e. US\$ 30134.34 and least in the year 2012 i.e. US\$10626.11. The contribution Household collection is least in total income of CF which is $3.78 \%$ (US\$6695.96), it was highest in the year 2016 (US\$1654.70) and least in the year 2012 (US\$1197.78). Funds from DFO/Organizations contributed US\$23965.44 in the total income and the contribution of other sources was US\$44886.39 in total (figure 3).

The total annual income was highest in the year 2014 i.e. US\$47557.75 and least in the year 2012 i.e. US\$23081.81. The total income increased in the second and third year then decreased in fourth year and again increased in the last year. The community forests are not only supplying the forest products but also helping the users group to generate the income. The management of community forest is good source of income (Lama, 2010, G.C. et al, 2016).

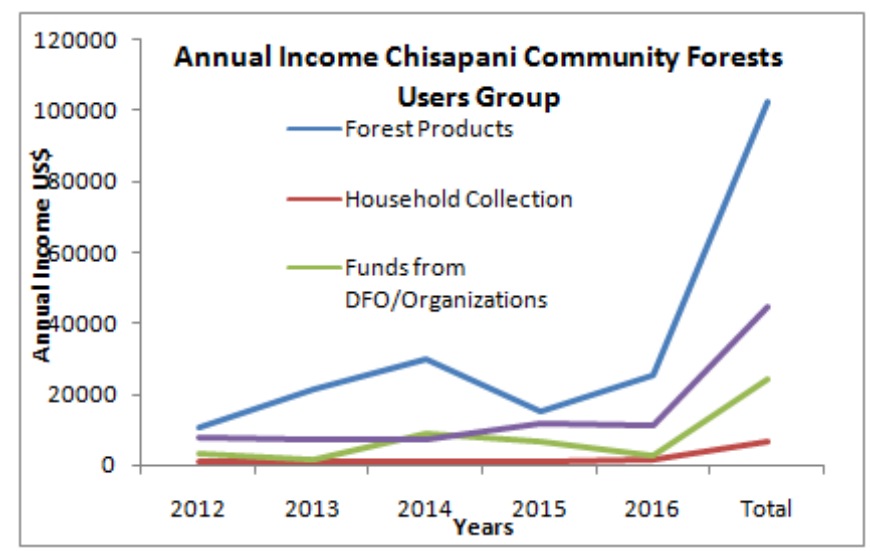

Figure3. Annual income of Chisapani CFUG from various sources in US\$

\subsection{Annual Expenditure of CFUGS}

\subsubsection{Annual Expenditure of Sansarkot Hariyali CFUG:}

CFUG was US\$ 71005.05 in between the year 2012-2016 out of that the expense was highest for the office management i.e.45.94\% (US\$ 32623.8). It was the highest expense in year 2016 (US\$ 16238.76) and least in the year 2012 (US\$2601.38) for the office management. In total the least expense was for the community development work i.e. 4.48\% (US\$ 3183.42). The expenses for the Forest development, income generation and other areas were 34.82\% (US\$24717.77), 9.60\% (US\$6813.9) and5.16\% (US\$3666.16) respectively (Figure 4).

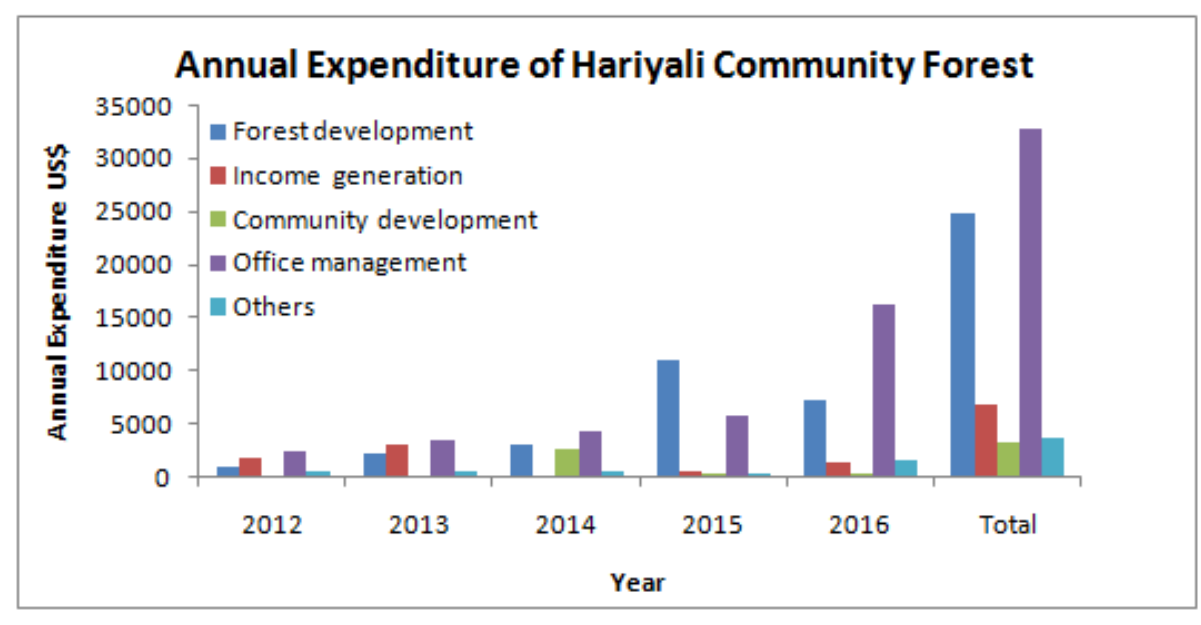

Figure4. Annual expenditure of Sansarkot Hariyali CFUG in various Areas in US\$ 
The total expense was highest in the year 2016 i.e. US\$ 26711.94 and least in the year 2012 i.e. US\$ 6133.03. The expenditure seems to be in increasing order from the year 2012-2016.

\subsubsection{Annual Expenditure of Parijat CFUG}

The total expenditure of Parijat CFUG was US\$ 56381.49 in between the year 2012-2016 out of that the expense was highest for the office management i.e.41.21\% (US\$23240.42). It was the highest expense in year 2012 (US\$ 8527.16) and least in the year 2016 (US\$2721.43) for the office management. The least expense was for income generation i.e. 3.54\% (US\$ 1993.42). The expenses for the Forest development, community development and other areas were 37.07\%\% (US\$20905.91), $12.77 \%$ (7196.14) and5.41\% (US\$ 3045.6) respectively (Figure 5).

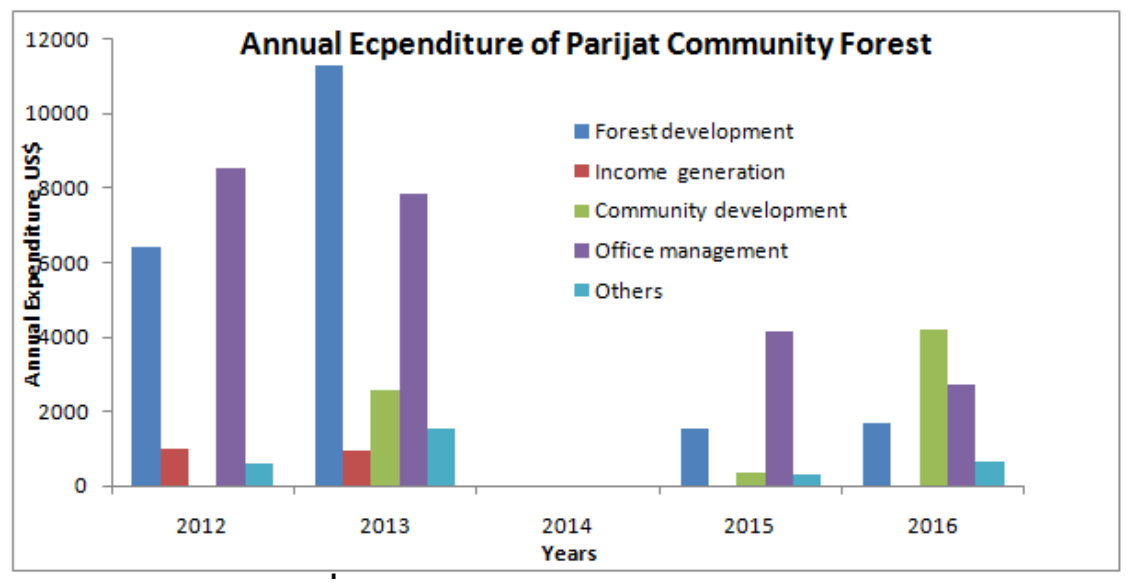

Figure5. Annual expenditure of Parijat CFUG in different area

The total expense was highest in the year 2013 i.e. US\$ 24191.03 and least in the year 2015 i.e. US\$ 6402.21. The expenditure increased in second year decreased in fourth year and again increased in last year.

\subsubsection{Annual Expenditure of Chisapani CFUG in Various Areas}

The total expenditure of Chisapani CFUG was US\$ 158082.01 in between the year 2012-2016 out of that the expense was highest for the Forest development i.e.44.85\% (US\$ 70896.3). It was the highest expense in year 2016 (US\$ 21684.95) and least in the year 2012 (US\$8295.77) for the forest development. In total the least expense was for the other areasi.e. 7.37\% (US\$ 11656.7). The expenses for the income generation, Community development and office management areas were $10.47 \%$ (US\$16555.92), 10.53\%\% (US\$16635.27) and26.78\% (US\$42337.82) respectively (Figure 6).

The total expense was highest in the year 2016 i.e. US\$ 38972.08 and least in the year 2012 i.e. US\$ 22820.12. The expenditure increased in second and third year, decreased in fourth year and again increased in last year. The national statistics of 2002 show that CFUGs are spending $28.5 \%$ of their income in forest protection and management, $2 \%$ in training and extension, $36 \%$ in community development activities, $14 \%$ as operational cost, $17 \%$ miscellaneous cost, $2 \%$ on training, study tour, workshops and 3\% on pro-poor programs (Kanel 2004), which contradict with this study as the share of expenses does not match with this study.Three years interim plan (2008-2010) has targeted to spend at least $35 \%$ of the total income in pro- poor programs but it was not followed in these CFUGs.

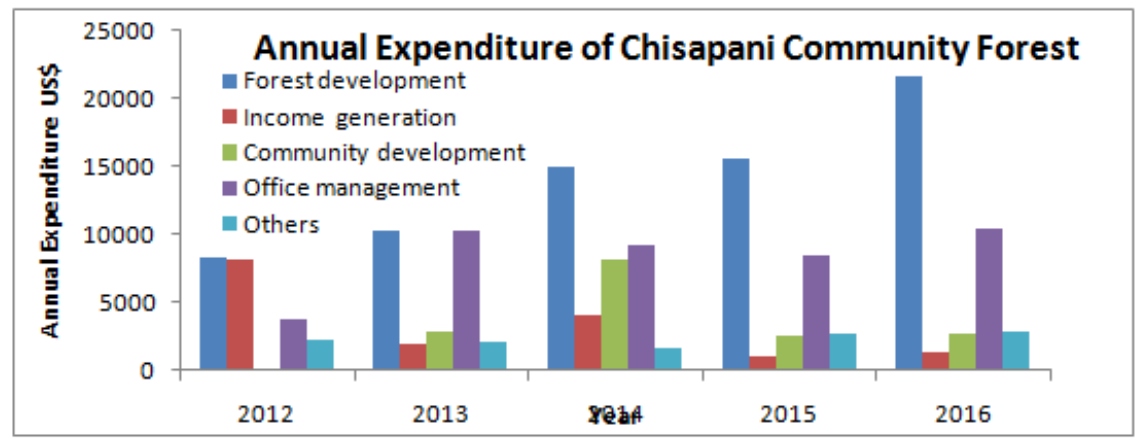

Figure6. Annual expenditure of Chisapani CFUG in different areas 
Pokharel (2008) in his study carried out in Lamjung, Tanahun and Gorkha describes that $55 \%$ of the annual investment of CFUGs is in public infrastructure, $22 \%$ in pro-poor activities, $17 \%$ in forest development and $6 \%$ in administration but in this study we found that very less amount is spend in the pro-poor programs and large amount is spend for the forest development and office management.

\subsection{Annual Profit, NPV and B/C of Cfugs}

In total the highest profit is obtained by Chisapani CFUG i.e. US\$ 19867.04 and the least profit is obtained by Parijat CFUG i.e. US\$ 4210.51 during past five years. The total profit of Sansarkot Hariyali CFUG is US\$ 7820.75. The profit trend of all the CFUGs is not in constant order. The NPV and $\mathrm{B} / \mathrm{C}$ is highest of the Chisapani CFUG i.e. US\$ 5322.69 and 1.11 and least of Parijat CFUG i.e. US\$3094.86 and 1.07 while NPV and B/C of Sansarkot Hariyali CFUG are US\$5322.69 and 1.11.

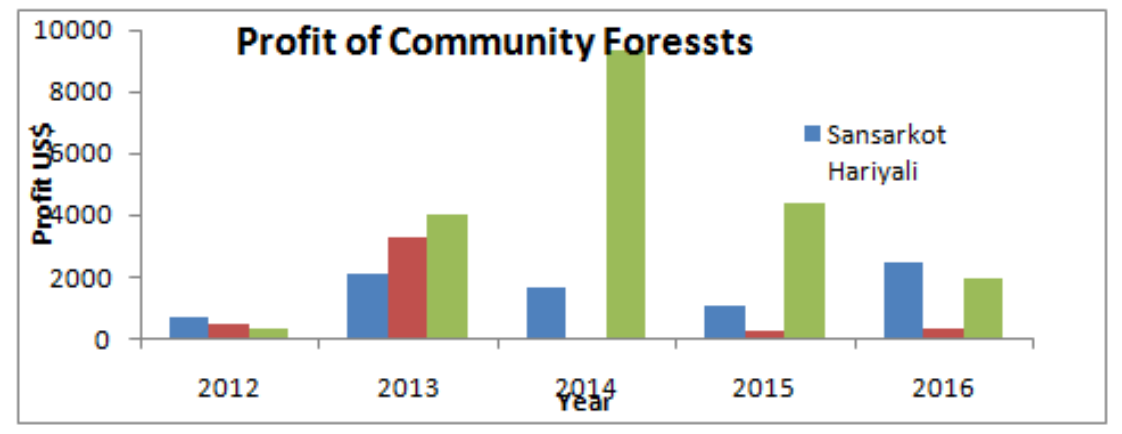

Figure7. Profit of Community Forest Users Group

Table1. NPV and B/C of CFUGs

\begin{tabular}{|l|l|l|l|}
\hline Community Forest & Total Profit & NPV & B/C \\
\hline Sansarkot Hariyali & 7820.75 & US\$ 5322.69 & 1.11 \\
\hline Parijat & 4210.51 & US\$3094.86 & 1.07 \\
\hline Chisapani & 19867.04 & US\$ 13646.84 & 1.12 \\
\hline
\end{tabular}

\section{CONCLUSION AND RECOMMENDATION}

The total income was found to be highest in Chisapani CFUG and the least in Parijat CFUG during last five years. The highest amount of expenditure was found in Chisapani CFUG and the least was in Parijat CFUG. The total profit is the highest for the Chisapani CFUG and least for the Parijat CFUG. The NPV and B/C was the highest of the Chisapani CFUG and it was the least of Parijat CFUG. Therefore, it is recommended that regular financial monitoring and evaluation is essential to show the performance of the community forest.

\section{REFERENCES}

[1] DoF, 2015. District Forest Office: An Introduction. District Forest Office. Nawalparasi, Nepal

[2] Acharya, K.P. 2001. Should community forest be Taned? Department of Forest Research and Survey, Nepal.

[3] Chhetri, B.B.K. (2006) community forestry programs in the hills of Nepal: Determinants of users participation and Household Dependency. M.Sc. Thesis, Norwegian University of Life Science (UMB0).

[4] Gilmour, D.A., and Fisher, R.J. (1991) villagers, forest and foresters: The philosophy, process and practice of community forestry in Nepal. Sahayogi press, Kathmandu.

[5] Kanel, K.R. and Kanel, B.R. (2004) Revising community forestry in Nepal: Achievements and challenges. Community forest bulletin 11:5-19. Community forestry division, Department of forest, Kathmandu, Nepal.

[6] Pokharel, B.K., Paudel, D. and Gurung, B.D. (2006) Forests, community based governance and livelihoods: Insights from the Nepal Swiss community forestry project in capitalization and sharing of experiences on the interaction between forest policies and land use patterns in Asia. Linking people with Resources, Vol2: Technical papers, 53-60. SDC and ICIMOD.

[7] Poudyal, B., Neil, P. and Alesion, G. (2006). Experiences and challenges of promoting pro-poor and social inclusion initiatives in user group forestry. Journal for livelihood, 5(1), 34-35.

[8] Richards, M., Maharjan, M.R. and Kanel, K.R. (2003) Economics, poverty and Transparency: Measuring equity in forest user groups. Forest and livelihood 3(1):91-104. 
[9] G.C. Dhruba Bijaya, Cheng1 S., Xu1 Z., Bhandari J., Wang L. and Liu X., 2016. Community forestry and livelihood in Nepal: a review, The Journal of Animal \& Plant Sciences, 26(1): 2016, Page: 1-12.

[10] Lama, G.K. 2010. Contribution of Community Forestry on Livelihood of Local Users.A case study from Study from Sunsari District, Nepal.Master Thesis(Unpublished).Tribhuwan University, Institute of Forestry Office of the Dean, Pokhara, Nepal.

[11] DoF,2016. Summary Statistics of Community Forest in Nepal. Community Forest Division, Department of Forests, Nepal.

Citation: Sampada Neupane and Ram Asheshwar Mandal*, " Economic Analysis of Community Forests in Terai Nepal'International Journal of Advanced Research in Botany, vol.6,no.1,p.1-8,2020. http://dx.doi.org/10.20431/ 2454-9444.06001001

Copyright: (C) 2020 Authors. This is an open-access article distributed under the terms of the Creative Commons Attribution License, which permits unrestricted use, distribution, and reproduction in any medium, provided the original author and source are credited. 